\title{
Phygitalarcheology for the Phlegraean Fields
}

\author{
Alessandra Pagliano \\ Greta Attademo \\ Anna Lisa Pecora
}

\section{Abstract}

The research investigates the theme of the valorization of the huge, but widespread, archaeological heritage of the Phlegraean Fields which, already weakened in its conservation and fruition by the bradyseismic phenomena of the area, is made even more fragile by the absence of narrative strategies, making even local communities unable to perceive its value. The study proposes a systematization of the knowledge of the Phlegraean Fields Park, through surveys and 3D models, integrated by the use of different digital technologies, which together promote effective forms of communication between users and heritage. Each site becomes the node of a network of thematic routes, traced starting from the major attractions of the area and aimed at defining a hybrid landscape, made of in site visits and immersive digital experiences. The goal is to generate a new model of inclusive museum, configuring cultural relationships between physically distant places, between lost spaces and real ruins.

Keywords

infoscape, ICT, AR, VR, archaeology, Phlegraean Fields.

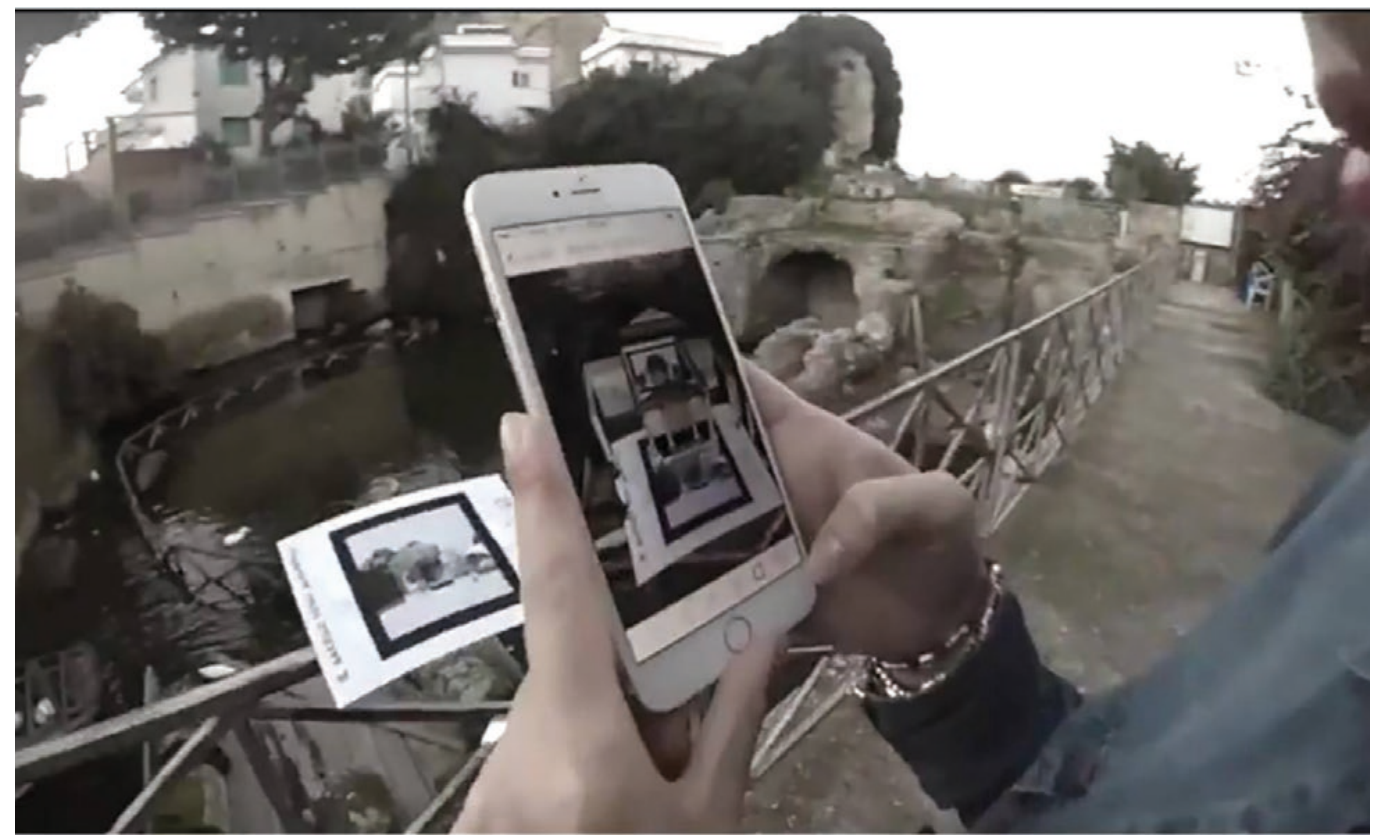




\section{Introduction}

The unique landscape of the Phlegraean Fields, as a palimpsest rewritten over the centuries by complex phenomena of volcanic nature, boasted in the years of the GrandTour an undisputed fame among European travelers. They recounted in numerous paintings and engravings the wonder and fascination of the ancient classical ruins of the Roman era immersed in a suggestive natural context. Since the 20th century, however, the link between nature and archaeological evidence has been abruptly altered by the unplanned expansion of the modern city, dominated by an uncontested and widespread building abuse. The close, and sometimes inseparable, connection between archaeological sites and modern construction [Di Liello 2005] has strongly influenced the methods of preservation and enhancement of the Greek-Roman remains. The Phlegraean Fields Archaeological Park, in fact, is a fragmented complex, consisting of twenty-five archaeological sites located even several kilometers apart. The Park has many problems, including the state of abandonment of large parts of the heritage, the lack of services, access and transport networks, as well as the inadequate participation of private individuals in the cycle of conservation, enhancement and management of cultural heritage. The impossibility of expropriating private buildings, moreover, does not allow the highlighting of archaeological assets, often even hidden by private individuals themselves. These critical points do not allow to enhance the heritage according to the most modern and shared strategies of conservation and musealization, nor to consistently organize the system of services for accessibility and presentation of architectural findings to the public. The aim of reconnecting the Phlegraean archaeological heritage encourages the search for a new communication strategy capable of integrating all the sites in the identity of a single large widespread park that, overcoming the physical fragmentation of today's urban fabric, can recompose the original and unitary territorial system of the Roman period.

\section{The Phigital Archeology Project}

The aim of returning the areas affected by the archaeological excavations to the life of the contemporary city, giving dignity and value to the ancient remains, has guided the research towards the use of appropriate digital communication technologies. These technologies not only allow to replace the physical visit where impractical for structural or security problems, but also to build new forms of relationship between citizens and the ancient urban fabric. ICT and digital networks increase, in fact, our ability to access information and, therefore, knowledge. The design of an integrated exhibition, partly physical and partly digital, made of real movements and virtual paths, physical spaces implemented and digital immersions, also allows to overcome the fragmentation of the Phlegraean archaeological heritage, creating new, more active and emotional ways of narration and fruition. The first step was the construction of a transversal corridor between places because "When we experience territories, we create stories. We model these stories using mental maps" [laconesi, Persico 2017, p. 277]. The creation of thematic maps, explorable and questionable, and narrative paths allows to connect archaeological sites even very different and distant, but linked by a common identity matrix. It involves placing certain sites in a thematic transect [Diedric, Lee, Braae 20I4], which creates connections even where they are no longer visible. The routes of visit and knowledge, organized according to the original use of the sites and included in a special interactive map in Google Mymaps, are:Theaters, Amphitheaters and Stadiums; Water Sites; Temples; Burial Sites (fig. I ). Each path, involving a large site attractor, could characterize the monthly tourist offer of the Park: in this way the minor sites could benefit from a flow of visitors not easily recallable, thus justifying the costs of the opening of some, otherwise visitable only on request. A process of digitization of the built heritage was then started, through a scientific collaboration agreement with the Park, using photogrammetric Structure-from-motion (SfM) survey techniques, which could return 3D mesh models with high definition textures. These models allow to reconstruct digitally a faithful hypothesis of the original configuration of the good, which becomes a tool of great effectiveness for the communication of the ancient value of the 
Fig. I.The four thematic routes for the Archaeological Park of Phlegraean Fields: Temples; Water places; Burial places; Theaters, amphitheaters and stadiums. monument. Despite the presence of numerous historical and architectural studies, in fact, the understanding of the archaeological vestiges continues to be difficult for the general public: the loss of the major volumes, coatings and colors, compromises the possibility of appreciating the heritage. The digital reconstruction of the original state, as well as the relocation of sculptural decorations lost or removed for protection needs, would allow the people of the Phlegraean municipalities, first of all, to suggestively enrich the emotional impact in situ, ensuring not only a deeper and more conscious path of knowledge, but also the definition of new relationships between the contemporary city and the ancient urban fabric. The digital models, moreover, constitute the indispensable basis for the technological tools with which we want to implement the narrative. The contextual use of augmented and virtual reality has been added to the more basic use of QR-Codes to link via web to multimedia content. The project also includes the physical installation of descriptive and graphic panels, which are intended to develop a new form of direct interaction between users and heritage.
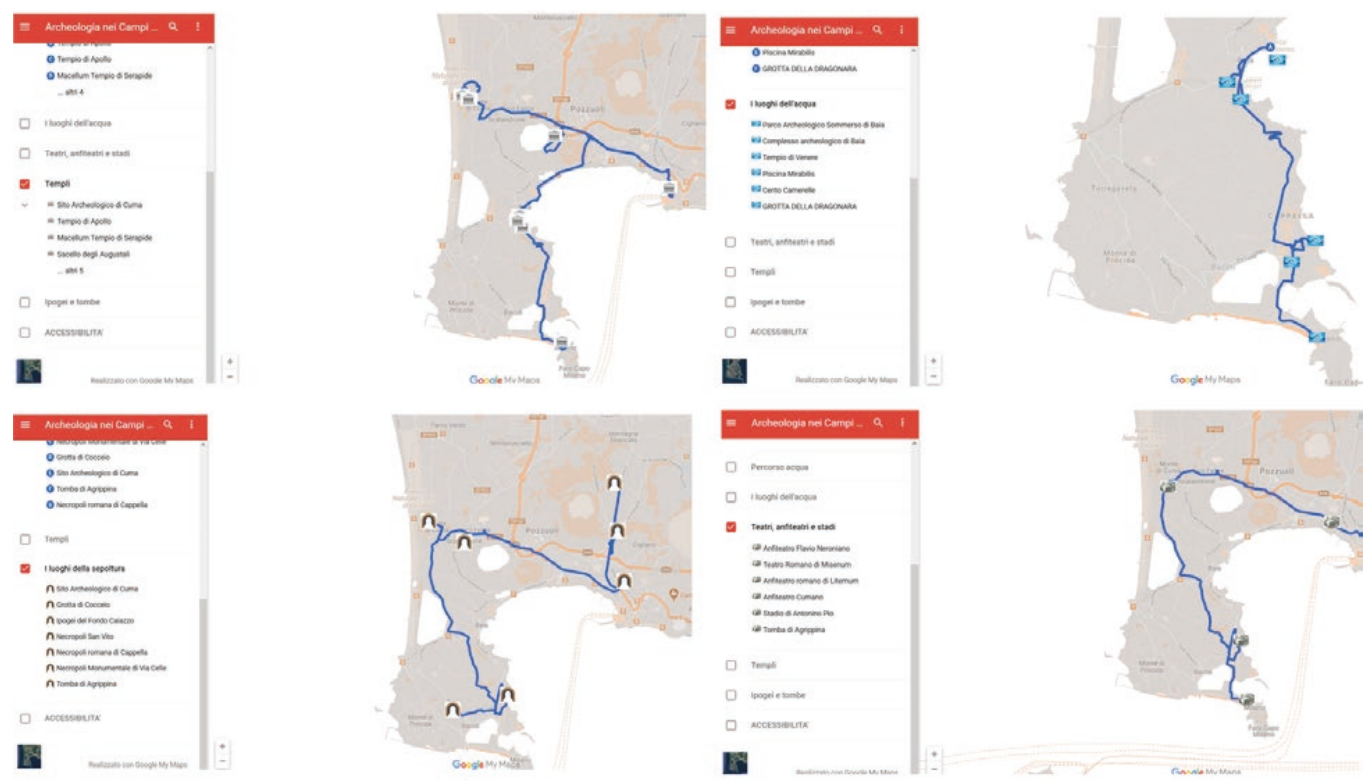

\section{Analogical and Digital Augmented Reality}

Augmented Reality is one of the choosen strategies, put in practice thanks to the open source app Augment since it allows you to overlay a new layer on archeological remains, the one of digital reconstruction of the structure. A 3D model of the real architecture is shaped through a philologically reconstruction, based on the literary sources and on similarities of coeval and affine buildings. Through the correct detection of an insertion point into the 3D model, the digital content becomes automatically visible in the camera while looking at a marker, that is associated with the 3D model's link while designing. This allows to project, in the same frame, the reconstruction of monument directly onto the archeological remains, completing them if necessary because they are incomplete, absent or unrecognizable due to the time. For example, the "Sepolcro di Agrippina", so called because of a wrong denomination during the XVI century, shows the ruins of an ancient theatre of Giulio-Claudia period. The loss of the top floor, cavea and stage that were the most characterizing elements of the typical theatral roman architecture, changes the original shape making it unrecognizable: the chance of exploring interactively the morphology and the spaces of a three dimensional model, created on an affordable reconstructing hypothesis, becomes a successful way to communicate even without specialized spectators, with difficulties in spatial imagination (fig. 2). This way, the user can experience the aspect ratio of the architecture reconstructed in its original shapes compared to his physical position, 
Fig. 2. Digital model of the 'Sepolcro di Agrippina' inserted in the Augment app for Augmented Reality (frame the marker with the with the scan of the app appear as in the photo).

changing the framing with the only obligation of sighting the marker printed on the panel. This way we provide a hybrid and multimodal experience where, the personal perception, physical and essential, of the visit to the archeological site, becomes an interactive tour. So the knowledge process is supported and implemented by the experience through information, spaces and digital objects integrated, in a mixed reality, to real ones. The design has a conceptual graphic style, with a simple monochromatic texture, that associates to the digital model the meaning of "drawing of real". Such choice allows the visitor being aware he's looking a likely reconstruction that doesn't excludes the further configurations as well as he can differ from the excessive hyperrealism of some augmented experiences that, aiming to sensationalism, make the observer a passive viewer rather than a visitor. In these case the archeological approach is drawn and influenced by technology [Volpe 2013]. The same goal is provided also thought the set-up of transparent panels that offer, for each archeological site, one or more perspective images, properly taken from the three dimensional reconstructed environment, reproducing the direct view that the observer would have of the archeological building in a particular position of the expositive path. The finding of the correct relation between archeological fragment and digital reconstruction is given to the visitor, that reassembles the view by overlaying three "red spots", existing in the drawing on the transparent panel, to the three corresponding markers applied on the equivalent points of the real physical structure. In this case we can talk of "analogical augmented reality" because this strategy is characterized by a real space augmented with new signs and high interactivity actively and emotionally involving the visitor to recognizing the lost parts related to the real ruins. The augmented reality, both analogical and digital, gives the chance to overcome the dichotomy between the physical and digital space (fig. 3). However, when some spaces are not accessible any more, it has been integrated with virtual reality experiences, ensuring the sensation of a physical experience inside buildings now impenetrable.
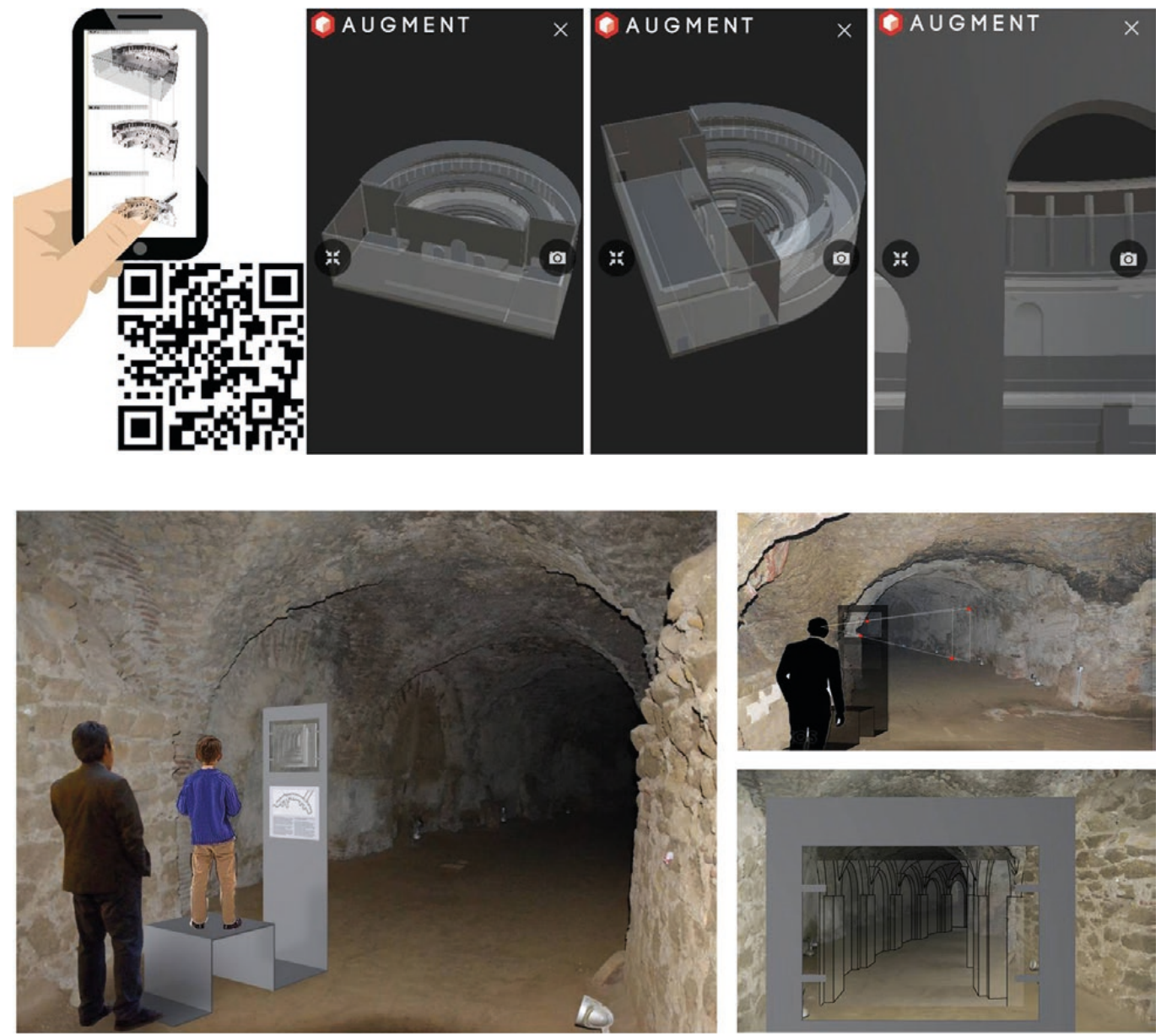


\section{Conclusions}

The proposed "Phygitalarcheology" project is an integrated set-up, partially physical and partially digital that allow to provide new kind of enjoyment, hybrid and multimodal, of archeological sites, ensuring new spatial relations among sites physically far each other, among lost spaces and real ruins, real and digital spaces. This integrated process generates a new model of museum, more inclusive, where digital information is not referred and attached only to the single object or site, but recombine, remix and recontextualize themselves creating always new physical and semantic geographies. The direct and fundamental experience of visiting the site, implemented by digital contents, becomes therefore a narrative-interactive path, encouraging not only the reconnection of the heritage diffused on the Phlegrean area, but even a new sense of knowledge of its value that would reconnect the citizens to their archeological heritage.

\section{References}

Annecchino Raimondo (2004). Bauli-Bacoli. Note storiche. Rist. In Giamminelli Raffaele (ed.). La 'Collezione Flegrea' di Raimondo Annecchino. Napoli:Adriano Gallina Editore.

Beloch Karl Julius (1989). Storia e topografia della Napoli antica e dei suoi dintorni. Napoli: Bibliopolis. Original: Campanien Gesuchite und Topographie des antiken Neapel un seiner Ungebung. II ed. Breslau: Morgenstern.

Catuogno Raffaele, Porfiri Francesca, Tacchi Gaia Lisa (2017). Survey for the enhancement of the archaeological sites of the Phlegraean Fields: the "Agrippina Sepulchre" in Bacoli. In IMEKO International Conference on Metrology for Archaeology and Cultural Heritage. Lecce: Curran Associates Inc., pp. 499-503.

Diedrich Lisa, Lee Gini. Braae Ellen (20 I4).TheTransect as a Method for Mapping and Narrating Water Landscapes: Humboldt's Open Works and Transareal Travelling. In NANO: New American Notes Online, 6, pp. 3- I 5.

Di Liello Salvatore (2005). Il paesaggio nei Campi Flegrei. Tra realtà e metafora. Napoli: Electa.

Gianolio Simone (ed.) (20 I 3). Archeologia Virtuale: comunicare in digitale. Roma: Espera.

laconesi Salvatore, Persico Oriana (2015). II Terzo Infoscape. Dati, informazioni e saperi nella città e nuovi paradigmi di interazione urbana. In Arcagni Simone (ed.). I media digitali e l'interazione uomo-macchina. Roma: Aracne Editore, pp. I39- I68.

laconesi Salvatore, Persico Oriana (2017). Digital Urban Acupuncture. Human Ecosystems and the Life of Cities in the Age of Communication, Information and Knowledge. Berlino: Springer.

Maiuri Amedeo (1995). II teatro-ninfeo detto "Sepolcro di Agrippina". In Anthemon. Scritti in onore di C. Anti. Firenze, pp. 263-271.

McGee Carrie, Rosenberg Francesca (2014). Art Making as Multisensory Engagement. Case Studies from The Museum of Modern. In Levent Nina, Pascual-Leone Alvaro (eds.). The Multisensory Museum: Cross-Disciplinary Perspectives on Touch, Sound, Smell, Memory, and Space. Lanham (MD): Rowman \& Littlefield Publishers, pp. 29-44.

Pagliano Alessandra (2015). II teatro perduto. Conoscenza e valorizzazione dei beni archeologici sepolti nel territorio di Miseno. In Giovannini Massimo, Di Luggo Antonella, Sacchi Livio, Gambardella Carmine (eds.). Spazi e culture del mediterraneo 4. Costruzione di un atlante del patrimonio culturale del mediterraneo. Napoli: La scuola di Pitagora editrice, pp. 2I 5-229.

Pagliano Alessandra (2017). Strategie comunicative per la valorizzazione dei beni culturali: la realtà aumentata per il Sacello degli Augustali a Miseno/ Communcative strategies for the enhancement of cultural heritage: Augmented Reality for the Sacellum of Augustales in Misenum. In Territori e frontiere della rappresentazione/ Territories and frontiers of representation. Roma: Gangemi editore International, pp. 555-564.

Volpe Giuliano (20/3). Archeologia, paesaggio e società al tempo della crisi: tra conservazione e innovazione, in Archeologia pubblica al tempo della crisi. In Parello Maria Concetta, Rizzo Maria Serena (eds.). Atti delle Giornate gregoriane. VII edizione, pp. $|83-19|$.

\section{Authors}

Alessandra Pagliano, Dept. of Architecture, University of Naples Federico II, alessandra.pagliano@unina.it

Greta Attademo, Dept. of Architecture, University of Naples Federico II, greta.attademo@unina.it

Anna Lisa Pecora, Dept. of Architecture, University of Naples Federico II, annalisa.pecora@unina.it 
